OCCASIONAL REVIEW

\title{
Does environmental endotoxin exposure prevent asthma?
}

\author{
J Douwes, N Pearce, D Heederik
}

Thorax 2002;57:86-90

The evidence as to whether exposure to environmental airborne endotoxin plays a protective or an inducing role in the development of asthma is reviewed. Studies of endotoxin and atopy, endotoxin and asthma, and farming and asthma are considered and, in each instance, a distinction is made between evidence of primary causation and evidence of secondary causation. It is concluded that, although it is plausible that bacterial endotoxin may protect against the development of asthma, there is considerable reason for caution regarding this hypothesis.

See end of article for authors' affiliations

Correspondence to: Dr J Douwes, IRAS, PO Box 80176,3508 TD, Utrecht,

The Netherlands;

j.douwes@iras.uu.nl

Accepted 19 September 2001 t has recently been suggested that exposure to environmental endotoxin might protect against the development of atopy and asthma..$^{1-5}$ This hypothesis has been prompted by various recent studies that reported a reduced risk of atopy (determined by skin prick tests, IgE serology or questionnaire), hay fever and, to a lesser extent, asthma in farmers' children and adolescents ${ }^{6-10}$ and in first year university students with a farming background. ${ }^{11}$ It was indicated that contact with livestock reduced the risk. ${ }^{710}$ This is consistent with previous observations that pigs and cattle in the home in Guinea-Bissau ${ }^{12}$ and Nepal, ${ }^{13}$ respectively, and the presence of pets in the home early in life in Europe ${ }^{14} 1^{15}$ were negatively associated with atopy. Although no specific protective factors were determined in these studies, it has been speculated that respiratory exposure to endotoxin (particularly in livestock farming) may play an important role $^{23}$ since it is well known, especially from occupational studies, that keeping animals is associated with strongly increased exposures to bacterial endotoxin.

The suggestions by Thomas ${ }^{16}$ that endotoxins are "read by our tissues as the very worst of bad news" and that in response to these molecules "we are likely to turn on every defence at our disposal" elaborate well the toxic potential of these macromolecules. ${ }^{17}$ Endotoxin is composed of lipopolysaccharides and is a non-allergenic cell wall component of Gram negative bacteria with strong pro-inflammatory properties. It is commonly present in many occupational environments ${ }^{18}$ and also in the general environment, particularly in house dust, as was first demonstrated by Peterson et $a l^{19}$ and more recently by others. ${ }^{20-22}$ There is ample evidence, mainly from studies in the work environment, that very high levels of exposure to endotoxin occur in farming, particularly livestock farming. ${ }^{23}$ Increased endotoxin levels were also found in homes where children had regular contact with farm animals ${ }^{2}$ and in those where pets were present. $^{22}$

It therefore seems plausible that bacterial endotoxin may account for the lower risk of atopy and perhaps asthma itself in farmers' children and, more generally, in the wider population. This hypothesis is appealing since it would not only account for the striking finding in farmers' children, but is also consistent with the "hygiene hypothesis" ${ }^{\prime 24}$ and would offer potential practical methods of asthma prevention. However, there is considerable reason for caution. In particular, although endotoxin exposure may protect against the development of atopy, at most only $50 \%$ of asthma cases appear to be attributable to mechanisms involving atopy. ${ }^{25}$ Moreover, it is well known from occupational health studies that exposure to endotoxin may induce asthma rather than protect against it (see below). Finally, there are many other factors that may explain the reduction of atopy in farmers' children-for example, high allergen exposure that may reduce the risk of sensitisation, infant infections, diet, and other lifestyle factors. These two aspects of the (potential) effects of endotoxin-namely, the protective effect with regard to atopy and endotoxin as an inducer of (occupational) asthma-have often not been carefully considered in discussing these issues. In this review we therefore consider the evidence as to whether environmental airborne endotoxin exposure plays a protective or inducing role in the development of asthma. In doing so, we distinguish between studies of endotoxin and atopy, endotoxin and asthma, and farming and asthma. Furthermore, in each instance we distinguish between evidence of primary causation and evidence of secondary causation. For clarity, we will only focus on the role of respiratory endotoxin exposure and will not discuss the potential immunomodulating role of gastrointestinal endotoxin. The latter may, however, be significant since it has been suggested that the intestinal microflora may be a very important source for microbial pressure potentially enhancing Thl type responses. ${ }^{26}$

\section{DEFINITIONS}

In this review we consider "atopy" as IgE mediated sensitisation to "common allergens" such as house dust mite, pets, and various other indoor and outdoor allergens. Asthma is defined as a chronic inflammatory disorder of the airways involving airflow limitation that is at least partly reversible and which results in recurrent episodes of symptoms such as wheezing, breathlessness, chest tightness, and cough. Allergic asthma represents asthma with an underlying atopic airway inflammation involving IgE sensitisation and eosinophils whereas non-allergic asthma is characterised by non-atopic airway inflammation (not involving $\operatorname{IgE}$ and eosinophils). 


\section{ENDOTOXIN AND ATOPY}

It has been proposed that bacterial endotoxin drives the response of the immune system-which is known to be strongly skewed in an atopic Th2 direction during fetal and perinatal life-in a Thl direction and away from its tendency to develop atopic immune responses. ${ }^{1}$ A more detailed overview of the proposed mechanisms is given elsewhere. ${ }^{27} 28$ Briefly, bacterial endotoxin can induce a significant production of interleukin (IL)-12 in antigen presenting cells which inhibits the atopic Th2 response by promoting and enhancing the Thl response. Endotoxin also induces interferon (IFN) $\gamma$ production which downregulates the maturation of $\mathrm{T}$ cells into Th2 cells. Furthermore, it has been shown that atopy (assessed as high serum IgE levels) is associated with a genetic polymorphism for $\mathrm{CDI} 4$, the lipopolysaccharide (endotoxin) receptor on monocytes and other inflammatory cells. ${ }^{29}$ However, to date only one small study has produced direct in vivo evidence that endotoxin exposure may protect against the development of atopy by enhancing Thl responses. In this study it was shown that, of 61 infants with a high risk for developing asthma, allergen sensitised infants had significantly lower house dust endotoxin levels than non-sensitised infants. ${ }^{4}$ They further showed in a subset of these infants that endotoxin levels correlated with IFN $\gamma$ producing T cells (Thl) but not with IL-4, IL-5, or IL-13 producing cell proportions (Th2). Finally, one study in ovalbumin sensitised rats found that airborne endotoxin exposure early in the sensitisation process ( 1 day before or within 4 days after intraperitoneal ovalbumin exposure) protected against the development of specific ovalbumin IgE antibodies. ${ }^{30}$ However, in complete contrast, another study showed that mice pre-exposed to airborne endotoxin ( 18 hours before and 5 days during airborne ovalbumin exposure) enhanced ovalbumin $\operatorname{IgE}$ sensitisation. ${ }^{31}$

A protective effect of endotoxin on the development of atopy therefore seems plausible, but the evidence is circumstantial since most data which support this hypothesis were produced in in vitro studies. In addition, the evidence from in vivo experiments in animals is mixed. If this protective effect does exist, it appears to involve prevention of primary causation through promotion of the Thl pathway.

\section{ENDOTOXIN AND ASTHMA}

With regard to asthma, the evidence is even more equivocal. The studies that have shown a consistent protective effect of farming exposure against atopy ${ }^{6-11}$ have shown only a weak protective effect against asthma itself. ${ }^{32}$

\section{"Endotoxin exposure may prevent the primary causation of allergic asthma, but it may be both a primary and secondary cause of non-allergic asthma"}

In fact, there is considerable evidence that endotoxin exposure may both exacerbate pre-existing asthma and induce new asthma in adults. In particular, endotoxin has been recognised as an important factor in the aetiology of occupational lung diseases including (non-allergic) asthma caused by organic dust exposure. ${ }^{33}$ Subjects exposed to pure endotoxin in inhalation experiments experience acute clinical effects such as fever, shivering, arthralgia, influenza-like symptoms (malaise), blood leucocytosis, neutrophilic airway inflammation, asthma symptoms such as dry cough, dyspnoea and chest tightness, bronchial obstruction, as well as dose dependent impairment of lung function (forced vital capacity (FVC), forced expiratory volume in 1 second $\left(\mathrm{FEV}_{1}\right)$, and flowvolume variables) and decreased lung transfer factor. ${ }^{34-39}$ In addition, in naive subjects challenged with endotoxincontaining cotton dust ${ }^{40}$ or dust from pig farms ${ }^{41}$ the same symptoms and lung function changes (including reversible airway obstruction) were demonstrated and they were most strongly associated with exposure to endotoxin and not with exposure to dust. Inhalation studies have further shown that subjects with increased bronchial hyperresponsiveness and/or asthma were more sensitive to developing symptoms. ${ }^{42-44}$ This has also been shown in a large epidemiological study of pig farmers. ${ }^{45}$ Furthermore, in healthy (non-allergic) subjects a highly variable (but reproducible) airway responsiveness to inhaled endotoxin was found, suggesting that only susceptible individuals are potentially at risk. ${ }^{46}{ }^{47}$

Acute airway effects found in experimental inhalation studies have been confirmed in many field studies conducted in farming and various other industrial environments. ${ }^{33}$ As long ago as 1961 it was proposed that inhalation of bacterial endotoxin was a causal factor in the development of occupational respiratory diseases in cotton workers. ${ }^{34}$ Since then, numerous studies have been conducted that indicated a causal role for endotoxin exposure in the pathogenesis of both reversible (asthma) and chronic airway obstruction, respiratory symptoms (symptoms of asthma, bronchitis and byssinosis), and increased airway responsiveness (summarised in table 1). This was consistently observed in various occupational environments characterised by different exposure levels and different compositions of the bioaerosol exposures. Several of these studies reported clear exposure-response relationships between endotoxin exposures and lung function effects and respiratory symptoms. ${ }^{55565863}$ Interestingly, one study by Zock et $a l^{53}$ showed that acute airway obstruction was already apparent at very low exposure levels of about $50 \mathrm{EU} / \mathrm{m}^{3}\left(\sim 5 \mathrm{ng} / \mathrm{m}^{3}\right)$, indicating that adverse respiratory effects (including asthma) may occur at very low levels.

Based on this evidence, "no effect levels" have been calculated and legal exposure standards for airborne endotoxin levels in the work environment have been proposed. ${ }^{69-71}$ These levels range from 50 endotoxin units $(\mathrm{EU}) / \mathrm{m}^{3}(\sim 5 \mathrm{ng} /$ $\mathrm{m}^{3}$ ) to several hundreds of $\mathrm{EU} / \mathrm{m}^{3}$, and are very low and thus highly prevalent in farming environments, particularly in those involved in livestock farming.

Several studies ${ }^{202266-68}$ have also shown that endotoxin in house dust is associated with exacerbations of pre-existing asthma in children and adults (see table 1). One cross sectional study performed in Belgium showed that domestic endotoxin levels in 69 adult patients with asthma were significantly correlated with a decrease in $\mathrm{FEV}_{1}$ and an increase in symptoms and daily need for oral and inhaled asthma medication. ${ }^{6}$ These results were confirmed in a Brazilian study in 10 asthmatic and 10 control children. ${ }^{67}$ Douwes et al ${ }^{22}$ have shown that endotoxin levels in house dust were positively associated with peak flow variability in asthmatic children but not in non-asthmatic children. After adjusting for the presence of pets in the home (which was significantly associated with high levels of endotoxin), the association with endotoxin disappeared. Interestingly, dust mite allergen levels were not associated with symptoms or lung function in these studies. Finally, one recent birth cohort study in 499 infants with a familial predisposition to asthma or allergy showed that early exposure to indoor endotoxin was associated with an increased (rather than a decreased) risk of repeated wheeze during the first year of life $(R R=1.6,95 \% \mathrm{CI}$ 1.03 to 2.38$){ }^{68}$

There is therefore consistent evidence that endotoxin can induce (at least in occupationally exposed populations) and exacerbate asthma. However, the underlying pathology is different from that observed in "classic" allergic/atopic asthma and does not include sensitisation and eosinophil involvement. The exact pathophysiology is not clear, but it is well established that it is mediated by an acute inflammatory response involving various cytokines including IL- 1 , IL-6, IL-8 and tumour necrosis factor (TNF)- $\alpha$, and the subsequent massive recruitment and activation of neutrophils in the lower and upper airways. ${ }^{37} 7273$ The inflammatory reactions are 
Table 1 Overview of epidemiological studies indicating adverse respiratory effects related to environmental endotoxin exposure

\begin{tabular}{|c|c|c|c|c|}
\hline Reference & Population & $\mathrm{N}$ & Exposure* & Health effect \\
\hline \multicolumn{4}{|c|}{ Occupational studies: } & Acute respiratory effects: \\
\hline 48 & Pig farm workers & 40 & $180 \mathrm{ng} / \mathrm{m}^{3}$ & Cross-shift decline in $\mathrm{FEV}_{1}$ and $\mathrm{MEF}_{25}$ \\
\hline 49 & Slaughter house workers & 23 & $20-1500 \mathrm{ng} / \mathrm{m}^{3}$ & $\begin{array}{l}\text { Cross-shift decline in FEV, and FVC; increased prevalence of respiratory } \\
\text { symptoms }\end{array}$ \\
\hline 50 & Animal feed workers & 119 & $29 \mathrm{ng} / \mathrm{m}^{3}$ & $\begin{array}{l}\text { Cross-shift decline in MMEF and } \mathrm{MEF}_{50} \text {; cross-week decline in } \mathrm{FEV}_{1} \text {, } \\
\mathrm{MEF}_{25}, \mathrm{MMEF} \text { and } \mathrm{MEF}_{50}\end{array}$ \\
\hline 51,52 & Fibreglass workers & 130 & $0.4-759 \mathrm{ng} / \mathrm{m}^{3}$ & $\begin{array}{l}\text { Cross-shift decline in PEF and } \mathrm{FEV}_{1} \text {; increased amplitude of PEF; increased } \\
\text { prevalence of respiratory symptoms and symptoms of fever, joint pains, } \\
\text { and influenza-like symptoms }\end{array}$ \\
\hline 53 & Potato processing workers & 61 & $21-56 \mathrm{EU} / \mathrm{m}^{3}$ & Cross-shift decline in FEV , and MMEF \\
\hline 54 & Potato processing workers & 97 & $534 \mathrm{EU} / \mathrm{m}^{3}$ & $\begin{array}{l}\text { Cross-shift decline in PEF; increased prevalence of respiratory symptoms } \\
\text { Chronic respiratory effects: }\end{array}$ \\
\hline 55 & Cotton mill workers & 443 & $2-550 \mathrm{ng} / \mathrm{m}^{3}$ & Decline in $\mathrm{FEV}_{1}$; increased prevalence of chronic bronchitis and byssinosis \\
\hline 56 & Pig farm workers & 183 & $130 \mathrm{ng} / \mathrm{m}^{3}$ & Decline in $\mathrm{FEV}_{1}$ and $\mathrm{FVC}$; increased prevalence of respiratory symptoms \\
\hline 57 & Cotton mill workers & 253 & $9-126 \mathrm{ng} / \mathrm{m}^{3}$ & Decline in $\mathrm{FEV}_{1}$ and $\mathrm{FVC}$; increased prevalence of respiratory symptoms \\
\hline 58 & Animal feed workers & 315 & $25 \mathrm{ng} / \mathrm{m}^{3}$ & Decline in $\mathrm{FEV}_{1}, \mathrm{FVC}, \mathrm{PEF}, \mathrm{MEF}_{75}, \mathrm{MEF}_{50}$ \\
\hline 59 & Cotton mill workers & 34 & $20-320 \mathrm{ng} / \mathrm{m}^{3}$ & Increase in bronchial hyperresponsiveness \\
\hline 60 & Pig farm workers & 54 & $11332 \mathrm{EU} / \mathrm{m}^{3}$ & $\begin{array}{l}\text { Decline in } \mathrm{FEV}_{1} \text { and FVC; increased prevalence of cough and chronic } \\
\text { bronchitis }\end{array}$ \\
\hline 61 & Grain workers & 410 & $2859 \mathrm{EU} / \mathrm{m}^{3}$ & Decline in $\mathrm{FEV}_{1}$; increased prevalence of respiratory symptoms \\
\hline $62 \dagger$ & Farm workers (pig farms/others) & $168 / 127$ & $588 / 410 \mathrm{EU} / \mathrm{m}^{3}$ & Longitudinal decline in $\mathrm{FEV}_{1}$ and $\mathrm{MMEF}$ \\
\hline $63+$ & Pig farm workers & 171 & $105 \mathrm{ng} / \mathrm{m}^{3}$ & Longitudinal decline in $\mathrm{FEV}_{1}$ \\
\hline $64 \dagger$ & Grain and animal feed workers & 140 & $3.6-99.0 \mathrm{ng} / \mathrm{m}^{3}$ & Longitudinal decline in $\mathrm{FEV}_{1}$ and MMEF \\
\hline $65 \dagger \S$ & Cotton mill workers & 366 & $\sim 3200 \mathrm{EU} / \mathrm{m}^{3}$ & Longitudinal decline in $\mathrm{FEV}_{1}$ and $\mathrm{FVC}$ \\
\hline \multicolumn{5}{|c|}{ Indoor studies: } \\
\hline 20 & Adult asthmatic patients & 28 & $2.59 \mathrm{ng} / \mathrm{mg}$ & $\begin{array}{l}\text { Decline in } F E V_{1} \text { and } F E V_{1} / F V C \text {; increase in asthma medication and } \\
\text { symptoms }\end{array}$ \\
\hline 66 & $\begin{array}{l}\text { Adult asthma (40)/rhinitis (29) } \\
\text { patients }\end{array}$ & 69 & $1.78 \mathrm{ng} / \mathrm{mg}$ & $\begin{array}{l}\text { Decline in } \mathrm{FEV}_{1} \text {, and } \mathrm{FEV}, / F V C_{\text {; }} \text { increase in asthma medication and } \\
\text { symptoms }\end{array}$ \\
\hline 67 & Children (50\% with asthma) & 20 & $1-100 \mathrm{EU} / \mathrm{mg}$ & Increase in asthma medication and symptoms in asthmatic children \\
\hline 22 & Children (50\% with airway symptoms) & 148 & $24.9 \mathrm{EU} / \mathrm{mg}$ & Increased PEF variability in atopic children with asthma symptoms \\
\hline $68 \dagger$ & Infants & 499 & $100 \mathrm{EU} / \mathrm{mg}$ & Increased prevalence of wheeze during first year of life \\
\hline \multicolumn{5}{|c|}{$\begin{array}{l}\mathrm{FEV}_{1}=\text { forced expiratory volume in } 1 \text { second; } \mathrm{FVC}=\text { forced vital capacity; } \mathrm{MEF}_{25}, \mathrm{MEF}_{50}, \mathrm{MEF}_{75}=\text { maximum expiratory flow rates at } 25 \%, 50 \% \text { and } 75 \% \\
\text { of the vital capacity; } \mathrm{MMEF}=\text { maximum mid expiratory flow; } \mathrm{PEF}=\text { peak expiratory flow. } \\
\text { *Exposure is expressed as the mean exposure (or range of (mean) exposures if no overall mean is given) in ng or endotoxin units per } \mathrm{m}^{3} \text { or per mg of } \\
\text { house dust; one endotoxin unit is approximately } 0.1 \mathrm{ng} \text { (the exact conversion factor varies depending on the source of endotoxin for calibration). } \\
\text { tLongitudinal study (all other studies were cross sectional studies) } \\
\text { †Association between endotoxin exposure and PEF variability disappeared after adjusting for pets in the home. } \\
\S 15 \text { year follow up of study by Kennedy et al in cotton mill workers. }\end{array}$} \\
\hline
\end{tabular}

orchestrated by alveolar macrophages that carry specific endotoxin binding receptors (CD14) which play a crucial role in the activation of these cells and the subsequent inflammatory processes. ${ }^{74}$ There is thus consistent evidence that endotoxin is both a secondary and primary cause of asthma and that this occurs through non-atopic - that is, non- $\operatorname{IgE}$ mediated-mechanisms.

\section{FARMERS AND ASTHMA}

A brief review of studies of farmers and their families seems appropriate here since it is primarily in this context that the hypothesis regarding the possible protective effects of endotoxin has arisen. As noted above, several studies have suggested a moderately decreased risk of asthma in farmers' children, adolescents, and students with a farming background. ${ }^{6-11}$ On the other hand, various studies have found a substantially increased risk of respiratory morbidity and mortality among adult farmers and farm workers ${ }^{23}$ despite their lower prevalence of smoking compared with the general population. $^{76}{ }^{77}$ In the European Community Respiratory Health Survey which investigated occupational asthma in 15637 randomly selected people aged 20-44, the highest risk of asthma was found for farmers (OR 2.6, 95\% CI 1.3 to 5.4 ) and agricultural workers (OR $1.8,95 \%$ CI 1.0 to 3.2 )..$^{78}$ An increased risk of asthma morbidity and mortality in farmers has also been reported in several other studies. ${ }^{79-81}$ Interestingly, in a Norwegian study of 8482 farmers and their spouses it was shown that subjects involved in animal production had a higher risk of asthma (OR 2.2, 95\% CI 1.1 to 4.2 ) than those not involved in animal production..$^{82}$ However, some studies have reported no additional risk or even a lower risk for asthma in farmers ${ }^{83} 84$ or young farmer students. ${ }^{85}$

Atopy has not been systematically studied in farmers since no controls were included in most studies so a direct comparison with the general population was not possible. However, several studies have reported relatively low prevalences of atopy, ${ }^{86-88}$ which suggests that the reduced risk of atopy in farmers' children continues into adult life. It therefore seems that asthma is more prevalent among adult farmers, despite the apparent lower prevalence of atopy and the slightly lower prevalence of asthma in farmers' children.

\section{CONCLUSIONS}

It is important to identify specific factors and underlying mechanisms that explain the protective effect of the farming environment on atopy, particularly in children, since this may result in novel approaches to preventing atopic diseases such as allergic asthma. Exposure to bacterial endotoxin in neonatal life has been proposed to play a role, and plausible mechanisms have been suggested. However, only limited and indirect evidence for this hypothesis is currently available, and there is consistent evidence that exposure to bacterial endotoxin may induce respiratory symptoms including (nonallergic) asthma in children and certainly in occupationally exposed adults. This apparent discrepancy in the potential role of endotoxin may be related to the timing (prenatal and neonatal versus child and adult life) and dose of exposure. A recent study by Park et $a l^{89}$ that measured airborne endotoxin 
in 15 homes in Boston (USA) reported a mean airborne endotoxin level of $0.64 \mathrm{EU} / \mathrm{m}^{3}$ (and a mean dust endotoxin level of 44-105 EU/mg), indicating that endotoxin exposures are likely to be much less than are usually encountered in the work environment (table 1). Nonetheless, occasional high(er) exposures to airborne endotoxin in the indoor environment may occur during specific activities in the home such as vacuum cleaning and, in the case of children, when playing on the floor close to dust reservoirs. Thus, if endotoxin exposure early in life indeed inhibits the development of atopy and allergic asthma, it may not necessarily reduce the prevalence of asthma in general since this effect may be counterbalanced by an increase in non-allergic asthma induced by (higher) endotoxin exposures later in life. This may be one of the reasons that atopy was clearly reduced in farmers' children whereas asthma symptoms were not (or only marginally) reduced, and asthma appears to be more common in farmers themselves.

In summary, although it is plausible that bacterial endotoxin may protect against the development of asthma, there is considerable reason for caution regarding this hypothesis. In particular: (1) a protective effect has only been established for atopy (and mainly for specific pollen sensitisation) and for hay fever; (2) the prevalence of asthma was only marginally reduced in children with frequent contact with animals, and it is not established that endotoxin is the aetiological factor; and (3) it is well established that endotoxin exposure itself may induce respiratory symptoms including (non-allergic) asthma symptoms. It therefore appears that endotoxin exposure may prevent the primary causation of allergic asthma, but it may be both a primary and secondary cause of non-allergic asthma. Further research is clearly needed, particularly of the timing and dose of endotoxin exposure. Several prospective birth cohort studies in both general and farming populations are currently in progress across Europe, the USA, and Brazil which focus on allergy, asthma, and early (including prenatal) endotoxin exposures and allergen exposure that may establish whether endotoxin prevents or induces asthma and at what levels of exposure. Some of those studies include a detailed characterisation of the T cell immune status (Th1, Th2 or Th3 immunity), providing important information on the causal mechanisms. Finally, in those children who develop asthma, it is interesting to determine whether they have developed allergic or nonallergic asthma since it is well known from occupational studies that endotoxin induces asthma through non-allergic mechanisms.

\section{ACKNOWLEDGMENTS}

The authors thank Bert Brunekreef for his critical comments on the draft manuscript. Neil Pearce is funded by the Health Research Council of New Zealand and Jeroen Douwes is supported by a research fellowship from the Netherlands Organisation for Scientific Research (NWO).

\section{Authors' affiliations}

J Douwes, D Heederik, Institute for Risk Assessment Sciences (IRAS), Division of Environmental and Occupational Health, Utrecht University The Netherlands

J Douwes, N Pearce, Centre for Public Health Research, Massey University Wellington Campus, Wellington, New Zealand

\section{REFERENCES}

1 Martinez FD, Holt PG. Role of microbial burden in aetiology of allergy and asthma. Lancet 1999;354:12-5.

2 Von Mutius E, Braun-Fahrlander C, Schierl R, et al. Exposure to endotoxin or other bacterial components might protect against the development of atopy. Clin Exp Allergy 2000;30:1230-4

3 Liu AH, Leung YM. Modulating the early allergic response with endotoxin. Clin Exp Allergy 2000;30:1535-9.
4 Gereda JE, Leung DYM, Thatayatikom A, et al. Relation between house-dust endotoxin exposure, type $1 \mathrm{~T}$-cell development, and allergen sensitisation in infants at high risk of asthma. Lancet 2000;355:1680-3

5 Gereda JE, Leung DYM, Liu AH. Levels of environmental endotoxin and prevalence of atopic disease. JAMA 2000;284:1652-3.

6 Braun-Fahrländer CH, Gassner M, Grize L, et al. Prevalence of hay fever and allergic sensitization in farmer's children and their peers living in the same rural community. Clin Exp Allergy 1999;29:28-34.

7 Riedler J, Eder W, Oberfeld G, et al. Austrian children living on a farm have less hay fever, asthma and allergic sensitization. Clin Exp Allergy 2000;30: 194-200.

8 Von Eherenstein OS, Von Mutius E, Illi S, et al. Reduced risk of hay fever and asthma among children of farmers. Clin Exp Allergy 2000;30: 187-93.

9 Ernst $\mathbf{P}$, Cormier $Y$. Relative scarcity of asthma and atopy among rural adolescents raised on a farm. Am J Respir Crit Care Med 2000;161:1563-6.

10 Downs SH, Marks GB, Mitakakis TZ, et al. Having lived on a farm and protection against allergic diseases in Australia. Clin Exp Allergy 2001;31:570-5

11 Kilpelaïnen $\mathbf{M}$, Terho $\mathrm{O}$, Helenius $\mathrm{H}$, et al. Farm environment in childhood prevents the development of allergies. Clin Exp Allergy 2000;30:201-8

12 Shaheen SO, Aaby P, Hall AJ, et al. Cell mediated immunity after measles in Guinea-Bissau: historical cohort study. BM 1996;313:969-74

13 Melsom T, Brinch L, Hessen JO, et al. Asthma and indoor environment in Nepal. Thorax 2001;56:477-81.

14 Svanes C, Jarvis D, Chinn S, et al, for the European Community Respiratory Health Survey. Childhood environment and adult atopy: results from the European Community Respiratory Health Survey. J Allergy Clin Immunol 1999;103:415-20.

15 Hesselmar N, Aberg N, Aberg B, et al. Does early exposure to cat or dog protect against allergy development? Clin Exp Allergy 1999.29:611-7.

16 Thomas I. The lives of a cell. Notes of a biology watcher. New York: The Viking Press, 1974: 78.

17 Morrison DC, Ryan JL. Bacterial endotoxins and host immune responses. Adv Immunol 1979;28:293-434.

18 Jacobs RR. Endotoxins in the environment. Int J Occup Environ Health 1997;3(suppl 1):S3-5.

19 Peterson RD, Wicklund PE, Good RA. Endotoxin activity of a house dust extract. Allergy 1964;35:134-42.

20 Michel O, Ginanni R, Duchateau J, et al. Domestic endotoxin exposure and clinical severity of asthma. Clin Exp Allergy 1991;21:441-8.

21 Douwes J, Doekes G, Heinrich J, et al. Endotoxin and $\beta(1 \rightarrow 3)$-glucan in house dust and the relation with home characteristics: a pilot study in 25 german houses. Indoor Air 1998;8:255-63.

22 Douwes J, Zuidhof A, Doekes G, et al. $\beta(1 \rightarrow 3)$-glucan and endotoxin in house dust and peak flow variability in children. Am J Respir Crit Care Med 2000;162:1348-54.

23 Schenker M, Cormier Y, Dimich-Ward H, et al. Respiratory health hazards in agriculture. Am J Respir Crit Care Med 1998;158/suppl 5, pt 2): $11-76$

24 Strachan DP. Hay fever, hygiene and household size. BM 1989;299: 1259-60.

25 Pearce N, Pekkanen J, Beasley R. How much asthma is really attributable to atopy? Thorax 1999;54:268-72.

26 Biörksten B. Perinatal events in relation to sensitization in the human. Am J Respir Crit Care Med 2000;162(suppl 3, pt 2):S105-7.

27 Holt PG, Sly PD, Björkstén B. Atopic versus infectious diseases in childhood: a question of balance? Pediatr Allergy Immunol 1997;8:53-8.

28 Martinez FD. Maturation of immune responses at the beginning of asthma. J Allergy Clin Immunol 1999;103:355-61.

29 Baldini M, Lohman IC, Halonen M, et al. A polymorphism in the $5^{\prime}$ flanking region of the CDI 4 gene is associated with circulating soluble CD1 4 levels and with total serum immunoglobulin E. Am J Respir Cell Mol Biol 1999;20:976-83.

30 Tulic MK, Wale JL, Holt PG, et al. Modification of the inflammatory response to allergen challenge after exposure to bacterial lipopolysaccharide. Am J Respir Cell Mol Biol 2000;22:604-12.

31 Wan GH, Li CS, Lin RH. Airborne endotoxin exposure and the development of airway antigen-specific allergic responses. Clin Exp Allergy 2000;30:426-32

32 Lewis SA. Animals and allergy. Clin Exp Allergy 2000;30:153-7.

33 Douwes J, Heederik D. Epidemiologic investigations of endotoxins. Int J Occ Env Health 1997;3(suppl 1):S26-31

34 Pernis B, Vigliani EC, Cavagna C, et al. The role of bacterial endotoxins in occupational diseases caused by inhaling vegetable dusts. $\mathrm{Br} J$ Ind Med 1961;18:120-9.

35 Michel O, Ginanni R, Le Bon B, et al. Inflammatory response to acute inhalation of endotoxin in asthmatic patients. Am Rev Respir Dis $1992 ; 146: 352-7$

36 Michel O, Duchateau J, Plat $G$, et al. Blood inflammatory response to inhaled endotoxin in normal subjects. Clin Exp Allergy 1995;25:73-9.

37 Michel O. Human challenge studies with endotoxins. Int J Occup Env Health 1997;3(suppl 1):S18-25.

38 Michel O, Nagy AM, Schroeven M, et al. Dose-response relationship to inhaled endotoxin in normal subjects. Am J Respir Crit Care Med 1997; 156: 1 157-64.

39 Thorn J, Rylander J. Inflammatory response after inhalation of bacterial endotoxin assessed by the induced sputum technique. Thorax 1998; 53: 1047-52 
40 Castellan RM, Olenchock SA, Kinsley KB, et al. Inhaled endotoxin and decreased spirometric values. N Engl J Med 1987;317:605-10.

41 Zhiping W, Malmberg P, Larsson BM, et al. Exposure to bacteria in swine-house dust and acute inflammatory reactions in humans. Am Respir Crit Care Med 1996;154:1261-6.

42 Zwan van der JC, Orie NMG, Kaufmann HF, et al. Bronchial obstructive reactions after inhalation with endotoxin and precipitinogens of Haemophilis influenzae in patients with chronic non-specific lung disease. Clin Allergy 1982;12:547-59.

43 Michel O, Duchateau J, Sergysels R. Effects of inhaled endotoxin on bronchial reactivity in asthmatic and normal subjects. J Appl Physiol 1989:66: 1059-64

44 Michel O, Ginanni R, Sergysels R. Relation between the bronchial obstructive response to inhaled lipopolysaccharide and bronchial responsiveness to histamine. Thorax 1992:47:288-91.

45 Preller L, Doekes G, Heederik D, et al. Exposure to disinfectants as a risk factor for atopic sensitization and the development of symptoms consistent with asthma. Eur Respir J 1996;9:1407-13.

46 Kline JN, Cowden JD, Hunninghake GW, et al. Variable airway responsiveness to inhaled lipopolysaccharide. Am J Respir Crit Care Med 1999:160:297-303

47 Michel O, Dentener M, Corazza F, et al. Healthy subjects express differences in clinical responses to inhaled lipopolysaccharide that are related with inflammation and with atopy. J Allergy Clin Immunol 2001;107:797-804.

48 Donham K, Haglind P, Peterson Y, et al. Environmental and health studies of farm workers in Swedish swine confinement buildings. $\mathrm{Br} J$ Ind Med 1989:46:31-7.

49 Hagmar L, Schütz A, Hallberg T, et al. Health effects of exposure to endotoxins and organic dust in poultry slaughter-house workers. Int Arch Occup Environ Health 1990;62:159-64.

50 Smid T, Heederik D, Houba, et al. Dust and endotoxin-related acute lung function changes and work-related symptoms in workers in the animal feed industry. Am J Ind Med 1994;25:877-88.

51 Milton DK, Amsel J, Reed CE, et al. Cross-sectional follow-up of a flu-like respiratory illness among fiberglass manufacturing employees: endotoxin exposure associated with two distinct sequelae. Am J Ind Med 1995;28:469-88.

52 Milton DK, Wypii D, Kriebel D, et al. Endotoxin exposure-response in a fiberglass manufacturing facility. Am J Ind Med 1996;29:3-13.

53 Zock JP, A Hollander, D Heederik, et al. Acute lung function changes and low endotoxin exposures in the potato processing industry. Am J Ind Med 1998;33:384-91.

54 Zock JP, Heederik D, Brunekreef B. Influence of shift work and host factors on endotoxin-related acute peak flow changes. Am J Respir Crit Care Med 1999;159:137-42

55 Kennedy SM, Christiani DC, Eisen EA, et al. Cotton dust and endotoxin exposure-response relationships in cotton textile workers. Am Rev Respir Dis 1987:135: 194-200.

56 Heederik D, Brouwer R, Biersteker K, et al. Relationship of airborne endotoxin and bacteria levels in pig farms with the lung function and respiratory symptoms of farmers. Arch Occup Environ Health 1991;62:595-601.

57 Sigsgaard T, Pedersen OF, Juul S, et al. Respiratory disorders and atopy in cotton, wool and other textile mill workers in Denmark. Am J Ind Med 1992;22:163-84.

58 Smid T, Heederik D, Houba R, et al. Dust and endotoxin related respiratory effects in the animal feed industry. Am Rev Respir Dis 1992;146:1474-9.

59 Rylander R, Bergstrom R. Bronchial reactivity among cotton workers in relation to dust and endotoxin exposure. Ann Occup Hyg 1993;37:57-63

60 Zejda JE, Barber E, Dosman JA, et al. Respiratory health status in swine producers relates to endotoxin exposure in the presence of low dust levels. J Occup Med 1994:36:49-56.

61 Schwartz DA, Thorne PS, Yagla SJ, et al. The role of endotoxin in grain dust-induced lung disease. Am J Respir Crit Care Med 1995;152:603-8.

62 Schwartz DA, Donham KJ, Olenchock SA, et al. Determinants of longitudinal changes in spirometric function among swine confinement operators and farmers. Am J Respir Crit Care Med 1995;151:47-53.

63 Vogelzang PF, van der Gulden JW, Folgering $H$, et al. Endotoxin exposure as a major determinant of lung function decline in pig farmers. Am J Respir Crit Care Med 1998;157:15-8.
64 Post W, Heedrik D, Houba R. Decline in lung function related to exposure and selection processes among workers in the grain processing and animal feed industry. Occup Environ Med 1998;55:349-55.

65 Christiani DC, Wang XR, Pan LD, et al. Longitudinal changes in pulmonary function and respiratory symptoms in cotton textile workers. A 15 year follow-up study. Am J Respir Crit Care Med 2001;163:847-53. 66 Michel O, Kips J, Duchateau J, et al. Severity of asthma is related to endotoxin in house dust. Am J Respir Crit Care Med 1996;154:1641-6.

67 Rizzo MC, Naspitz CK, Fernandez-Cladas E, et al. Endotoxin exposure and symptoms in asthmatic children. Pediatr Allergy Immunol 1997;8:121-6.

68 Park JH, Gold DR, Spiegelman DL, et al. House dust endotoxin and wheeze in the first year of life. Am J Respir Crit Care Med $2001 ; 163: 322-8$

69 Heederik D, Douwes J. Towards an occupational exposure limit for endotoxins? Ann Agric Environ Med 1997:4:17-19.

70 Rylander R. Evaluation of the risks of endotoxin exposure. Int J Occup Environ Health 1997;3(suppl 1):S32-6.

71 Dutch Expert Committee on Occupational Standards (DECOS) Endotoxins: health based recommended exposure limit. A report of the Health Council of the Netherlands. Publication no 1998/03WGD. Rijswijk: Health Council of the Netherlands, 1998.

72 Sandström T, Bjermer L, Rylander R. Lipopolysaccaride (LPS) inhalation in healthy subjects increases neutrophils, lymphocytes and fibronectin levels in bronchoalveolar lavage fluid. Eur Respir J 1992;5:992-6.

73 Becker S, Clapp WA, Quay J, et al. Compartmentalization of the inflammatory response to inhaled grain dust. Am J Respir Crit Care Med 1999:160:1309-18.

74 Wright SD, Ramos RA, Tobias PS, et al. CD14, a receptor for complexes of lipopolysaccharide (LPS) and LPS binding protein. Science 1990;249: 1431-3.

75 Ulmer AJ. Biochemistry and cell biology of endotoxins. Int J Occup Environ Health 1997;3(suppl 1):S8-17.

76 Sterlin TD, Weinkam JJ. Smoking patterns by occupation, industry, sex and race. Arch Environ Health 1978;33:313-7.

77 Stellman SD, Boffetta P, Garfinkel L. Smoking habits of 800,000 American men and woman in relation to their occupations. Am J Ind Med $1988 ; 13: 43-58$.

78 Kogevinas M, Anto JM, Sunyer J, et al. Occupational asthma in Europe and other industrialised areas: a population-based study. Lancet 1999;353:1750-4

79 Toren K, Horte L-G, Jarvholm B. Occupation and smoking adjusted mortality due to asthma among swedish men. $\mathrm{Br} J$ Ind Med 1991:48:323-6.

80 Neijari C, Tessier JF, Letenneur L, et al. Prevalence of self-reported asthma symptoms in a French elderly sample. Respir Med 1996;90:401-8.

81 Fishwick D, Pearce N, D'Souza W, et al. Occupational asthma in New Zealanders: a population based study. Occup Environ Med 1997;54:301-6.

82 Melbostad E, Eduard W, Magnus P. Determinants of asthma in a farming population. Scand J Work Environ Health 1998;24:262-9.

83 Vogelzang PF, van der Gulden JW, Tielen M, et al. Health-based selection for asthma, but not for chronic bronchitis, in pig farmers: an evidence-based hypothesis. Eur Resp J 1999;13:187-9.

84 Kimpbell-Dunn M, Bradshaw L, Slater T, et al. Asthma and allergy in New Zealand farmers. Am J Ind Med 1999;35:51-7.

85 Omland $O$, Sigsgaard T, Hjort $C$, et al. Lung status in young Danish rurals: the effect of farming exposure on asthma-like symptoms and lung function. Eur Respir J 1999;13:31-7.

86 Van Hage-Hamsten M, Johansson SG, Zetterstrom O. Predominance of mite allergy over allergy to pollens and animal danders in a farming population. Clin Exp Allergy 1987;17:417-23.

87 Blainey AD, Topping MD, Ollier S, et al. Respiratory symptoms in arable farmworkers: role of storage mites. Thorax 1988;43:697-702.

88 Iversen $\mathbf{M}$, Pedersen B. The prevalence of allergy in Danish farmers. Allergy 1990;45:347-53.

89 Park JH, Spiegelman DL, Burge HA, et al. Longitudinal study of dust and airborne endotoxin in the home. Environ Health Perspect 2000; 108: 1023-8. 